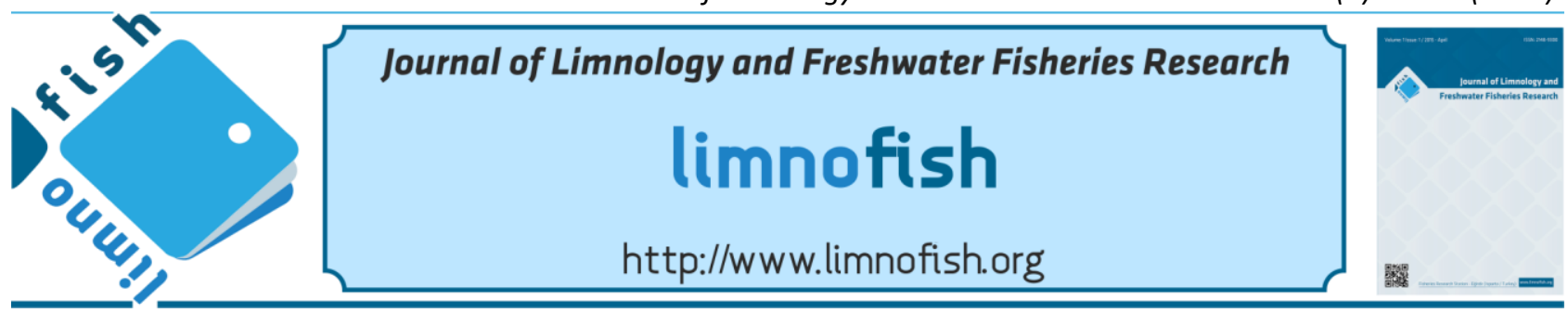

\title{
Increasing Shelf Life of Sous-Vide Cooked Rainbow Trout by Natural Antioxidant Effective Rosemary: Basic Quality Criteria
}

\author{
Soner ÇETINKAYA ${ }^{1 * \mathbb{D}}$, Şengül BILLGIN ${ }^{2}$, , Ömer Osman ERTAN ${ }^{2}$ (D) \\ ${ }^{1}$ Eğirdir Fisheries Research Institute, Isparta, Türkiye \\ ${ }^{2}$ Suleyman Demirel University, Eğirdir Fisheries Faculty, Isparta, Türkiye
}

\section{A B STRACT}

In the study, the rosemary was applied as a natural antioxidant after grinding. Dust ground rosemary were applied on the fillet surface $(0.1 \%$ percent of the fillets weight), and then were packaged with the vacuum and sous-vide processed. Every five days, chemical composition, $\mathrm{pH}$, TVB-N, TBARS analyzes and sensorial assessment was carried out until the spoilage. The ash, moisture, protein, and lipid content of raw rainbow trout was $1.63 \pm 0.11 \%, 78.36 \pm 0.18 \%$, $16.49 \pm 0.20 \%$, and $3.37 \pm 0.30 \%$, respectively. The $\mathrm{pH}$ value raw fish was $6.29 \pm 0.01$. TVB-N values were determined between $12.86 \pm 0.15$ and $21.94 \pm 0.29$ $\mathrm{mg} / 100 \mathrm{~g}$. in RAG. The highest TBARS value was determined as $0.80 \pm 0.03$ in RAG. Odor parameter was effective to deteriorate the decision of panelists for all the samples The vacuum packaged fresh fish (VFF) was spoiled in the $10^{\text {th }}$ days while, the rosemary untreated group (RUG) was spoiled in the $40^{\text {th }}$ days, and rosemary applied group (RAG) was spoiled in the $45^{\text {th }}$ days. With the rosemary treatment, the shelf life and acceptability of the samples was extended to at least 5 days. Also, applied rosemary as the natural antioxidant had no negative effects with regard to sensory and nutritional criteria.

Keywords: TVB-N, TBARS, sensorial assessment, chilled storage, spoilage

\section{ARTICLE INFO}

$\begin{array}{lll}\text { RESEARCH ARTICLE } & \\ \text { Geliş } & : 02.06 .2017 \\ \text { Düzeltme } & : 31.07 .2017 \\ \text { Kabul } & : 10.08 .2017 \\ \text { Yayım } & : 21.08 .2017\end{array}$

DOI: $10.17216 /$ LimnoFish.318327

\section{*CORRESPONDING AUTHOR}

cetinson_70@hotmail.com

Tel : +902463133460

Doğal Antioksidan Etkili Biberiye ile Sous-Vide Pişirilmiş Gökkuşağı Alabalığının Raf Ömrünün Artırılması: Temel Kalite Kriterleri

Öz: Çalıșmada, ögütülmüş biberiye doğal bir antioksidan olarak uygulandı. Yüzeyine toz halindeki biberiye uygulanan alabalık filetoları, vakumda paketlendikten sonra sous-vide işlemine tabi tutuldu. Örnekler bozuluncaya kadar beş günde bir kimyasal kompozisyon, pH, TVB-N, TBARS analizleri ve duyusal değerlendirme yapıldı. Çalışmada kullanılan gökkuşağı alabalığ 1 filetolarının kül, nem, protein ve lipid içeriği sırasıyla \%1,63 $\pm 0,11, \% 78,36 \pm 0,18, \% 16,49 \pm 0,20$ ve $\% 3,37 \pm 0,30$ olarak belirlendi. Taze balık etinin $\mathrm{pH}$ değeri 6,29 $\pm 0,01$ 'di. RAG'de TVB-N değerleri 12,86 $\pm 0,15$ ile 21,94 $\pm 0,29 \mathrm{mg} / 100 \mathrm{~g}$ arasında tespit edildi. En yüksek TBARS değeri RAG'de $0,80 \pm 0,03$ olarak belirlendi. Koku parametresi, tüm örnekler için panelistlerin bozulma kararı vermesinde belirleyici oldu. Vakum paketlenmiş taze balık (VFF) 10. günde bozulmuşken, biberiye ile muamele edilmemiş grup (RUG) 40. günde bozuldu ve biberiye uygulanan grup (RAG) 45. günde bozuldu. Biberiye muamelesiyle, numunelerin raf ömrü ve kabul edilebilirliği en az 5 güne kadar uzatılmıştır. Ayrıca, yapılan duyusal analizlere göre doğal antioksidan olarak uygulanan biberiyenin duyusal ve beslenme kriterleri açısından olumsuz bir etkisi olmadığı belirlendi.

Anahtar Kelimeler: TVB-N, TBARS, duyusal değerlendirme, soğuk depolama, bozulma

\section{Alıntılama}

Çetinkaya S, Bilgin Ş, Ertan, ÖO. 2017. Increasing Shelf Life of Sous-Vide Cooked Rainbow Trout by Natural Antioxidant Effective Rosemary: Basic Quality Criteria. LimnoFish. 3(2): 69-77. doi: 10.17216/LimnoFish.318327

\section{Introduction}

The desire for a healthy and long life is a commonly accepted merit for humankind. The numbers of health problems are rising in both developed and developing countries with increasing population. The focused research on plant-based diets and functions of phytochemicals for nutrition and ageing brought clarity to progress (Poyrazoğlu and Velioğlu 2005; Meskin et al. 2008). The studies showed polyphenols and carotenoids have riskreducing effects of certain cancers and cardiovascular diseases besides health-promoting properties (Meskin et al. 2008). So, those adverse effects were seen of artificial antioxidants, the need for natural antioxidants has increased and the work in this area has focused on plant-derived antioxidants (Diri 
2006a). Recent years, a lot of studies were carried out about antioxidant and antimicrobial properties of rosemary had significant phytochemicals resource (Genena et al. 2008; Klančnık et al. 2009; Abramovic et al. 2012; Altınelataman et al. 2015; Azizkhani and Tooryan 2015).

Fisheries product is a significant natural source of unsaturated fatty acid like as DHA (22:6n-3) and EPA (20:5n-3) (Eseceli et al. 2006; Nollet and Toldrá 2010). But, lipid peroxidation is the most restrictive factor for shelf life of the fish oil. Also, it was admitted the most important factor for shelf life determination of those product if the microbiological effects omitted. Reaction products of lipid oxidation have an adverse effect on the sensorial properties of fish products. The secondary volatile products of oxidation, especially derived from unsaturated fatty acid (like as n-3 group) have adverse effect on the general appreciation even in low quantities (Nollet and Toldrá 2010).

Nowadays, consumers mostly prefer the food, that with fresh tasty, high-quality, low salt contain, non additives, and in a short prepared time. In accordance with those demands, had significantly increased of the production of ready to eat foods, of which minimally processed, and shelf life prolonged by cooling, and heatable with microwave owen, in the European and American markets. Such processed products, also consists sous-vide processed products, are called "new generation chilled products" (Novak et al. 2003).

The sous-vide technology is a pasteurization application for vacuumed foods. Using this technique, ensured the food shelf life with the cold storage, and therefore it has increased importance day to day. To apply this technology, the foods cook in a vacuum package with or without spices or sauces, and could be serviced after by heating with hot water or microwave oven. In this respect, the sous-vide technology or vacuum packed cooking technique is an application that can service to the catering sector. Also, for the preservation of rapidly perishable foods is very convenient. Because fisheries products are easily perishable foods, so, it is reported to be suitable for make packaging using this technology, by researchers (Mol and Özturan 2009).

There were reported that no adequate scientific studies about sous-vide treated fisheries products (Fagan and Gormley 2005; Mol and Özturan 2009). Also, the conducted studies were about microbiological properties of products. According to the results of those studies, any problem microbiologically was not seen, but the deterioration occured along the storage period came true on the sensorial properties (Bolton 1998; Kılınç and Caklı 2001; Lindström et al. 2003; Novak et al. 2003;
Garcia-Linares et al. 2004; Gonzales-Fandos et al. 2004; Gonzales-Fandos et al. 2005; Cobos and Diaz 2007; Diaz et al. 2008; Diaz et al. 2009; Shakila at al. 2009; Diaz et al. 2010;). So, in this study it was aimed to determination of changes on the quality properties, especially sensorial attributes, along the storage period. This study was carried out determination effects of rosemary as a natural antioxidant on the nutritional composition, and quality properties of rainbow trout, which cooked sous-vide method and cold stored.

\section{Materials and Methods \\ Materials and sample preparation}

This study was conducted on fresh, vacuumed, sous vide processed, and rosemary (Rosmarinus officinalis Linn. Lamiaceae) applied and sous vide processed fish groups. Totally $15 \mathrm{~kg}$ rainbow trout in the study were filleted, weighed, equally divided (150 g) (15 packets for every groups), and were kept in deep freezer $\left(-18^{\circ} \mathrm{C}\right)$ until usage (The average total length of the fish is $25 \mathrm{~cm}$ and the average weight is $250 \mathrm{gr})$. The rosemary is a plant, which have phenolic compounds. In this study, the rosemary (pine - leaf) was used as a natural antioxidant additive. The rosemary, reaped in a local garden, cleaned dust by the tap water. Than it was dried in the air flow and shadow place, and stored within nonpermeable bags in the cool and shadow place until use. The vacuum bags (cast PP) were provided by a commercial company (Apack Ambalaj Makine Sanayi ve Tic. Ltd. Sti. in Istanbul-Türkiye). $\mathrm{O}_{2}$ permeability of vacuum bag material is $22.56 \mathrm{cc} / \mathrm{m}^{2} /$ day $\left(24{ }^{\circ} \mathrm{C}\right)$, and one bag is $2.71 \mathrm{cc} /$ day $\left(24{ }^{\circ} \mathrm{C}\right)$. The $\mathrm{CO}_{2}$ permeability of material is 95.64 $\mathrm{cc} / \mathrm{m}^{2} /$ day $\left(24{ }^{\circ} \mathrm{C}\right)$, and one bag is $11.48 \mathrm{cc} /$ day $\left(24{ }^{\circ} \mathrm{C}\right)$. Also heat resistance of the material is $25 / 150{ }^{\circ} \mathrm{C}$. Total thickness of one bag is $0.88 \mathrm{~mm}$.

The fillets were melted under the tap water (the water temperature was $14{ }^{\circ} \mathrm{C}$ ). Grounded rosemary (like dust) was weighed as $0.1 \%$ percent of the fillets weight (Selmi and Sadok 2008). Rosemary applied on the fillets surfaces then the fillets were put into the bag and vacuumed. The cooking was made in $85^{\circ} \mathrm{C}$ benmari for 35 minutes (SVAC 1991; Peck 1997). Than, the packets were dipped in a bucket with $1 / 3$ water and $2 / 3$ iced, so rapidly cooled to $3-4{ }^{\circ} \mathrm{C}$, in the 30 minutes. All packets were stored in the refrigerator at $3 \pm 1{ }^{\circ} \mathrm{C}$ until to spoil.

\section{Analytical methods}

Total antioxidant effect, free radical scavenging capacity and total phenolic content of rosemary was determined. Total antioxidant effect was determined by $\beta$-carotene-linoleic acid assey (Dapkevicius et al. 1998; Diri 2006a). Free radical scavenging capacity 
was determined 1.1-difenil-2-pikrilhidrazil (DPPH system) (Tepe et al. 2005; Diri 2006b; Selmi and Sadok 2008). Total phenolic content was determined by Folin-Ciocalteu assay (Oktay et al. 2003; Diri 2006b).

The ash and total lipid analysis were conducted according to Lovell (1981). Moisture content was determined by AND MX-50 automatic moisture analysis (Oven Drying Method). Protein contents were determined by Velp UD-20 protein predigested unit and fully automatic Velp UDK 142 distillation unit by Kjeldahl methods (Nx6.25) (AOAC 2000). $\mathrm{pH}$ of the samples was measured with automatic $\mathrm{pH}$ meter (WTW 320 set digital) diluted by 1/10 (w/v) ratio (Varlık et al. 2007). Total volatile basic nitrogen (TVB-N) determined by a method had informed by Nicholas (2003). The thiobarbituric acid-reactive substances (TBARS) were analyzed using a method modified by Erkan and Özden (2007). Fatty acids analysis was conducted by Perkin Elmer Clarus 500 (GC) in fresh fish and RAG. For this purpose a flame ionization detector (FID) and a silica AGE colon ( $30 \mathrm{~m}$ x $0.32 \mathrm{~mm}$ ID x $0.25 \mu \mathrm{m}$, BP20 0.25 UM, USA) and Supelco FAME 37 mix was used.

\section{Sensorial analyses}

Sensorial analyses were conducted with a hedonic scale (Huss 1995; Altuğ and Elmac1 2005; Diaz et al. 2009; Shakila et al. 2009). In the every session, the experienced 10 panelists were assessed the micro-wave heated $100 \mathrm{~g}$ samples descriptive and affective tests for color, smell, taste, texture, appearance, juiciness, general appreciation. If the group score equal to 2 points or lower were accepted had spoiled (Huss 1995; Altuğ and Elmac1 2005; Diaz et al. 2009; Shakila et al. 2009).

\section{Statistical analyses}

The analyses were conducted for fresh fish (FF), vacuum packaged fresh fish (VFF), the rosemary untreated group (RUG), and rosemary applied group (RAG) samples to observe changes along the storage period in every 5 days. All analyses and measurements were made triplicate. The data analyzed by ANOVA (Özdamar 2001) using SPSS 15 (95\% confidence interval). The appeared differences for the treatments ( $0^{\text {th }}$ day) on the stored samples had determined with Duncan test. Also, of the rosemary treatment effects determined by t test between RUG and RAG along the storage period, and marked on the tables as + (significant), and (insignificant).

\section{Results}

The rosemary was used as a natural antioxidant in this study. Total antioxidant effect, free radical scavenging capacity and total phenolic content of rosemary was determined as $97.76 \pm 1.92 \%$, $8.76 \pm 0.57 \%, \quad 128.95 \pm 0.00 \mathrm{mg} / \mathrm{l}$ gallic acid equivalent, respectively.

No significant effects were determined related to vacuuming, sous vide treatment, or sous vide treatment with rosemary application to the ash content of FF, VFF, RUG, and RAG group (Table 1). Solely, a significant difference was seen between RUG and RAG on the $15^{\text {th }}$ day. No significant differences were seen in the in-group values along the storage period.

The moisture content of samples had not effected by the treatment or application. The highest and the lowest moisture values were obtained in the $35^{\text {th }}$ storage days (Table 2). The differences between in the groups were found significant in the RUG and RAG along the storage period $(\mathrm{p} \leq 0.05)$.

The protein was affected by vacuuming and rosemary application significantly $(\mathrm{p}<0.05)$. The protein value had shown differences statistically significant $(\mathrm{p} \leq 0.05)$ for the RUG and RAG on the $15^{\text {th }}, 30^{\text {th }}$, and $40^{\text {th }}$ day (Table 3 ).

Significant differences statistically $(\mathrm{p} \leq 0.05)$ observed in the the total lipid values for intragroup and among the groups (Table 4). But, a significant statistical difference ( $p>0.05)$ was not seem between RUG and RAG.

The rosemary treatment affected the $\mathrm{pH}$ until to the $20^{\text {th }}$ day (Table 5). Along the storage progresses, this effect was not observed. In the generally, the $\mathrm{pH}$ value of RAG had higher than RUG. The $\mathrm{pH}$ values of RAG had shown statistically significant change $(\mathrm{p} \leq 0.05)$ in the intragroup.

The application of rosemary and than vacuuming has shown decrease effect in the initial value of TVB$\mathrm{N}$. The TVB-N value of RUG had higher than the fresh samples in the first day. Statistically significant difference $(\mathrm{p} \leq 0.05)$ was seem between groups TVB$\mathrm{N}$ value of both RUG and RAG (Table 6). But, application rosemary has statistically significant $(p \leq 0.05)$ effect on the TVB-N value on the $0^{\text {th }}$ day and $30^{\text {th }}$ day.

In the initially, the TBARS value was close the each other for all groups. However, the changes in the TBARS value was found to be statistically no significant $(p>0.05)$ in $0^{\text {th }}$ day. Significant difference statistically $(p \leq 0.05)$ had seen in the TBARS value of the intragroups and among the groups (Table 7).

The RAG group had preferred mostly for the color criteria. The smell criteria score was affective to taken in to the decision of spoilage of samples. The RUG achieved the highest taste score. When the sample had spoiled, the taste point has approached to the spoilage point, (Table 8). 
Table 1. Ash contents of groups for storage days (\%)

\begin{tabular}{|c|c|c|c|c|c|}
\hline $\begin{array}{lll}\text { Days } & \text { Groups } \\
\end{array}$ & FF & VFF & RUG & RAG & Sig. $t$ test \\
\hline $\mathbf{0}$ & $1.63 \pm 0.11^{\mathrm{a}}$ & $1.62 \pm 0.02^{\mathrm{Aa}}$ & $1.86 \pm 0.45^{\mathrm{Aa}}$ & $1.73 \pm 0.23^{\mathrm{Aa}}$ & - \\
\hline 5 & & $1.57 \pm 0.02^{\mathrm{A}}$ & $1.85 \pm 0.03^{\mathrm{A}}$ & $1.82 \pm 0.12^{\mathrm{A}}$ & - \\
\hline 10 & & $1.65 \pm 0.03^{\mathrm{A}}$ & $1.55 \pm 0.03^{\mathrm{A}}$ & $1.61 \pm 0.13^{\mathrm{A}}$ & - \\
\hline 15 & & & $1.55 \pm 0.04^{\mathrm{A}}$ & $1.94 \pm 0.05^{\mathrm{A}}$ & + \\
\hline 20 & & & $1.78 \pm 0.13^{\mathrm{A}}$ & $1.93 \pm 0.14^{\mathrm{A}}$ & - \\
\hline 25 & & & $1.83 \pm 0.09^{\mathrm{A}}$ & $1.84 \pm 0.06^{\mathrm{A}}$ & - \\
\hline 30 & & & $1.75 \pm 0.03 \mathrm{~A}$ & $1.86 \pm 0.07 \mathrm{~A}$ & - \\
\hline 35 & & & $1.85 \pm 0.01^{\mathrm{A}}$ & $1.74 \pm 0.09^{\mathrm{A}}$ & - \\
\hline 40 & & & $1.74 \pm 0.06^{\mathrm{A}}$ & $1.66 \pm 0.08^{\mathrm{A}}$ & - \\
\hline 45 & & & & $1.64 \pm 0.06^{\mathrm{A}}$ & NT \\
\hline
\end{tabular}

* The same lowercase for treatment and the same capital letter for the storage period are statistically insignificant $(p>0.05)$. The effects of rosemary treatment were marked as + (significant), and - (insignificant). *NT (Not Tested)

Table 2. Moisture contents of groups for storage days (\%)

\begin{tabular}{|c|c|c|c|c|c|}
\hline $\begin{array}{ll}\text { Days } & \text { Groups }\end{array}$ & FF & VFF & RUG & RAG & Sig. $t$ test \\
\hline $\mathbf{0}$ & $78.36 \pm 0.18^{\mathrm{a}}$ & $78.80 \pm 0.40^{\mathrm{Aa}}$ & $78.83 \pm 0.23 \mathrm{Aa}$ & $78.41 \pm 0.06^{\mathrm{ABa}}$ & - \\
\hline 5 & & $78.52 \pm 0.48^{\mathrm{A}}$ & $76.69 \pm 0.82^{\mathrm{BE}}$ & $79.60 \pm 0.10^{\mathrm{A}}$ & - \\
\hline 10 & & $78.69 \pm 0.16^{\mathrm{A}}$ & $78.58 \pm 0.10^{\mathrm{A}}$ & $77.84 \pm 0.67^{\text {В }}$ & - \\
\hline 15 & & & $77.51 \pm 0.38 \mathrm{AB}$ & $78.39 \pm 1.14 \mathrm{AB}$ & + \\
\hline 20 & & & $78.66 \pm 0.25^{\mathrm{A}}$ & $78.49 \pm 0.17^{\mathrm{AB}}$ & - \\
\hline 25 & & & $78.56 \pm 0.25^{\mathrm{A}}$ & $79.72 \pm 0.02^{\mathrm{A}}$ & - \\
\hline 30 & & & $78.13 \pm 0.89 \mathrm{AB}$ & $79.26 \pm 0.39 \mathrm{AB}$ & - \\
\hline 35 & & & $76.55 \pm 0.89^{\mathrm{B}}$ & $79.79 \pm 0.34^{\mathrm{A}}$ & - \\
\hline 40 & & & $78.33 \pm 0.31 \mathrm{AB}$ & $79.31 \pm 0.24 \mathrm{AB}$ & - \\
\hline 45 & & & & $78.86 \pm 0.21 \mathrm{AB}$ & NT \\
\hline
\end{tabular}

* The same lowercase for treatment and the same capital letter for the storage period are statistically insignificant $(\mathrm{p}>0.05)$. The effects of rosemary treatment were marked as + (significant), and - (insignificant). *NT (Not Tested)

Table 3. Protein contents of groups for storage days (\%)

\begin{tabular}{|c|c|c|c|c|c|}
\hline $\begin{array}{ll}\text { Days } & \text { Groups }\end{array}$ & FF & VFF & RUG & RAG & Sig. $t$ test \\
\hline $\mathbf{0}$ & $16.49 \pm 0.20^{\mathrm{ab}}$ & $16.89 \pm 0.07^{\mathrm{Aa}}$ & $16.39 \pm 0.23^{\mathrm{Aab}}$ & $16.40 \pm 0.10^{\mathrm{Ab}}$ & - \\
\hline 5 & & $16.86 \pm 0.26^{\mathrm{A}}$ & $16.92 \pm 0.13 \mathrm{AB}$ & $16.54 \pm 0.13^{\mathrm{AB}}$ & - \\
\hline 10 & & $16.44 \pm 0.09^{\mathrm{A}}$ & $16.82 \pm 0.16^{\mathrm{AB}}$ & $16.95 \pm 0.28^{\mathrm{BC}}$ & - \\
\hline 15 & & & $16.95 \pm 0.10^{\mathrm{AB}}$ & $16.59 \pm 0.06^{\mathrm{AB}}$ & + \\
\hline 20 & & & $16.58 \pm 0.35^{\mathrm{AB}}$ & $16.93 \pm 0.37^{\mathrm{BC}}$ & - \\
\hline 25 & & & $16.54 \pm 0.06^{\mathrm{AB}}$ & $16.53 \pm 0.05 \mathrm{AB}$ & - \\
\hline 30 & & & $16.83 \pm 0.15^{\mathrm{AB}}$ & $17.72 \pm 0.11^{\mathrm{D}}$ & + \\
\hline 35 & & & $17.03 \pm 0.05^{\text {В }}$ & $16.91 \pm 0.19^{\mathrm{BC}}$ & - \\
\hline 40 & & & $16.88 \pm 0.06^{\mathrm{AB}}$ & $17.35 \pm 0.09^{\mathrm{CD}}$ & + \\
\hline 45 & & & & $17.11 \pm 0.09^{\mathrm{BC}}$ & NT \\
\hline
\end{tabular}

* The same lowercase for treatment and the same capital letter for the storage period are statistically insignificant $(\mathrm{p}>0.05)$. The effects of rosemary treatment were marked as + (significant), and - (insignificant). *NT (Not Tested)

Table 4. Total lipid contents of groups for storage days (\%)

\begin{tabular}{|c|c|c|c|c|c|}
\hline $\begin{array}{ll} & \text { Groups } \\
\text { Days } & \end{array}$ & FF & VFF & RUG & RAG & Sig. $t$ test \\
\hline $\mathbf{0}$ & $3.37 \pm 0.30^{\mathrm{a}}$ & $3.31 \pm 0.21 \mathrm{Aa}$ & $3.29 \pm 0.30^{\mathrm{Ba}}$ & $3.39 \pm 0.17^{\mathrm{Da}}$ & - \\
\hline 5 & & $3.42 \pm 0.82^{\mathrm{A}}$ & $2.65 \pm 0.00^{\mathrm{AB}}$ & $2.42 \pm 0.19 \mathrm{AB}$ & - \\
\hline 10 & & $3.48 \pm 0.18^{\mathrm{A}}$ & $3.05 \pm 0.57 \mathrm{AB}$ & $2.82 \pm 0.08^{\mathrm{BC}}$ & - \\
\hline 15 & & & $2.59 \pm 0.09^{\mathrm{C}}$ & $2.46 \pm 0.14^{\mathrm{E}}$ & - \\
\hline 20 & & & $2.39 \pm 0.08 \mathrm{AB}$ & $2.99 \pm 0.25^{\mathrm{CD}}$ & - \\
\hline 25 & & & $2.58 \pm 0.27^{\mathrm{AB}}$ & $1.97 \pm 0.17^{\mathrm{A}}$ & - \\
\hline 30 & & & $2.37 \pm 0.40 \mathrm{AB}$ & $1.95 \pm 0.17^{\mathrm{A}}$ & - \\
\hline 35 & & & $2.42 \pm 0.23 \mathrm{AB}$ & $2.38 \pm 0.02^{\mathrm{AB}}$ & - \\
\hline 40 & & & $2.14 \pm 0.35 \mathrm{AB}$ & $1.95 \pm 0.17^{\mathrm{A}}$ & - \\
\hline 45 & & & & $2.69 \pm 0.07^{\mathrm{BC}}$ & NT \\
\hline
\end{tabular}

* The same lowercase for treatment and the same capital letter for the storage period are statistically insignificant (p > 0.05). The effects of rosemary treatment were marked as + (significant), and - (insignificant). *NT (Not Tested) 
Table 5. The $\mathrm{pH}$ values of groups for storage days

\begin{tabular}{|c|c|c|c|c|c|}
\hline $\begin{array}{ll}\text { Days } & \text { Groups } \\
\end{array}$ & FF & VFF & RUG & RAG & Sig. $t$ test \\
\hline $\mathbf{0}$ & $6.29 \pm 0.01^{\mathrm{a}}$ & $6.30 \pm 0.27^{\mathrm{Ba}}$ & $6.46 \pm 0.01^{\mathrm{Ab}}$ & $6.54 \pm 0.02^{\mathrm{Cc}}$ & + \\
\hline 5 & & $6.39 \pm 0.01^{\mathrm{C}}$ & $6.61 \pm 0.01^{\mathrm{B}}$ & $6.13 \pm 0.07^{\mathrm{A}}$ & + \\
\hline 10 & & $6.05 \pm 0.01^{\mathrm{A}}$ & $6.76 \pm 0.01^{\mathrm{D}}$ & $6.84 \pm 0.01^{\mathrm{G}}$ & + \\
\hline 15 & & & $6.91 \pm 0.00^{\mathrm{E}}$ & $6.93 \pm 0.00^{\mathrm{H}}$ & + \\
\hline 20 & & & $6.71 \pm 0.01^{\mathrm{C}}$ & $6.73 \pm 0.01^{\mathrm{F}}$ & - \\
\hline 25 & & & $6.70 \pm 0.01^{\mathrm{C}}$ & $6.69 \pm 0.01 \mathrm{EF}$ & - \\
\hline 30 & & & $6.62 \pm 0.01^{\mathrm{B}}$ & $6.65 \pm 0.01 \mathrm{DE}$ & - \\
\hline 35 & & & $6.61 \pm 0.01^{\mathrm{B}}$ & $6.59 \pm 0.00^{\mathrm{CD}}$ & - \\
\hline 40 & & & $6.63 \pm 0.01^{\mathrm{B}}$ & $6.59 \pm 0.00^{\mathrm{CD}}$ & + \\
\hline 45 & & & & $6.46 \pm 0.01^{\mathrm{B}}$ & NT \\
\hline
\end{tabular}

* The same lowercase for treatment and the same capital letter for the storage period are statistically insignificant $(\mathrm{p}>0.05)$. The effects of rosemary treatment were marked as + (significant), and - (insignificant). *NT (Not Tested)

Table 6. The TVB-N values of groups for storage days $(\mathrm{mg} / 100 \mathrm{~g})$

\begin{tabular}{|c|c|c|c|c|c|}
\hline $\begin{array}{ll}\text { Days } & \text { Groups }\end{array}$ & FF & VFF & RUG & RAG & Sig. $t$ test \\
\hline $\mathbf{0}$ & $14.71 \pm 0.17^{\mathrm{a}}$ & $11.68 \pm 0.47^{\mathrm{Ac}}$ & $15.55 \pm 0.55^{\mathrm{Aa}}$ & $13.36 \pm 0.00^{\mathrm{ABb}}$ & + \\
\hline 5 & & $14.04 \pm 0.61^{\mathrm{A}}$ & $14.20 \pm 0.34 \mathrm{AB}$ & $13.36 \pm 0.67 \mathrm{AB}$ & - \\
\hline 10 & & $18.32 \pm 1.98^{\mathrm{B}}$ & $12.69 \pm 0.34^{\mathrm{A}}$ & $14.04 \pm 0.44^{\mathrm{B}}$ & - \\
\hline 15 & & & $13.45 \pm 0.22^{\mathrm{A}}$ & $12.86 \pm 0.15^{\mathrm{A}}$ & - \\
\hline 20 & & & $13.70 \pm 0.08^{\mathrm{A}}$ & $13.95 \pm 0.22^{\mathrm{B}}$ & - \\
\hline 25 & & & $16.14 \pm 0.52^{\mathrm{CD}}$ & $16.56 \pm 0.22^{\mathrm{D}}$ & - \\
\hline 30 & & & $17.31 \pm 0.83^{\mathrm{D}}$ & $13.70 \pm 0.08^{\mathrm{AB}}$ & + \\
\hline 35 & & & $16.39 \pm 0.44^{\mathrm{CD}}$ & $15.72 \pm 0.30^{\mathrm{CD}}$ & - \\
\hline 40 & & & $15.80 \pm 0.69^{\mathrm{CD}}$ & $15.13 \pm 0.15^{\mathrm{C}}$ & - \\
\hline 45 & & & & $21.94 \pm 0.29^{\mathrm{E}}$ & NT \\
\hline
\end{tabular}

* The same lowercase for treatment and the same capital letter for the storage period are statistically insignificant $(\mathrm{p}>0.05)$. The effects of rosemary treatment were marked as + (significant), and - (insignificant). *NT (Not Tested)

Table 7. The TBARS values of groups for storage days ( $\mu \mathrm{g} \mathrm{MDA} / \mathrm{g}$ )

\begin{tabular}{|c|c|c|c|c|c|}
\hline Days $\quad-$ Groups & FF & VFF & RUG & RAG & Sig. $t$ test \\
\hline $\mathbf{0}$ & $0.25 \pm 0.03^{\mathrm{a}}$ & $0.32 \pm 0.03^{\mathrm{Aab}}$ & $0.35 \pm 0.04^{\mathrm{Ab}}$ & $0.27 \pm 0.00^{\text {Aab }}$ & - \\
\hline 5 & & $0.43 \pm 0.04^{\mathrm{A}}$ & $0.31 \pm 0.08^{\mathrm{A}}$ & $0.11 \pm 0.00^{\mathrm{A}}$ & - \\
\hline 10 & & $1.29 \pm 0.10^{\text {В }}$ & $0.43 \pm 0.07^{\mathrm{A}}$ & $0.55 \pm 0.03^{\mathrm{CD}}$ & - \\
\hline 15 & & & $0.80 \pm 0.03^{\text {В }}$ & $0.36 \pm 0.07 \mathrm{BC}$ & + \\
\hline 20 & & & $0.92 \pm 0.05^{\mathrm{BC}}$ & $0.65 \pm 0.06^{\mathrm{DEF}}$ & + \\
\hline 25 & & & $1.00 \pm 0.05^{\mathrm{C}}$ & $0.78 \pm 0.05^{\mathrm{EF}}$ & + \\
\hline 30 & & & $0.93 \pm 0.04^{\mathrm{BC}}$ & $0.59 \pm 0.03^{\mathrm{DE}}$ & + \\
\hline 35 & & & $1.38 \pm 0.05^{\mathrm{D}}$ & $0.80 \pm 0.03^{\mathrm{F}}$ & + \\
\hline 40 & & & $1.01 \pm 0.04^{\mathrm{C}}$ & $0.65 \pm 0.03 \mathrm{DEF}$ & + \\
\hline 45 & & & & $0.75 \pm 0.17 \mathrm{DEF}$ & NT \\
\hline
\end{tabular}

* The same lowercase for treatment and the same capital letter for the storage period are statistically insignificant $(p>0.05)$. The effects of rosemary treatment were marked as + (significant), and - (insignificant). *NT (Not Tested)

The texture score of VFF was decreased rapidly on $10^{\text {th }}$ day. The same decrease was not seem in the other groups. The used technology was effective to the texture score of samples. The highest appearance score was obtained for RUG, and RAG on the $15^{\text {th }}$ day.

The appearance score of RUG had higher than RAG's on the $20^{\text {th }}, 25^{\text {th }}$ and $30^{\text {th }}$ days (Table 8 ). The significant differences $(p \leq 0.05)$ had seen in the juiciness score. The highest score was obtained on the $5^{\text {th }}$ day. General appreciation score, which reflected the consumer pleasure, was decrease by the elongation of the storage period.

\section{Acknowledgment}

This study partially summarized the $\mathrm{PhD}$ Thesis "The effect of natural antioksidants on quality characteristics chill stored sous vide processed rainbow trout (Oncorhynchus mykiss Walbaum, 1792)" of Soner ÇETINKAYA supported by Süleyman Demirel University with a BAP Project number which is 2464-D-10. The authors declared that they have no conflict of interest. 


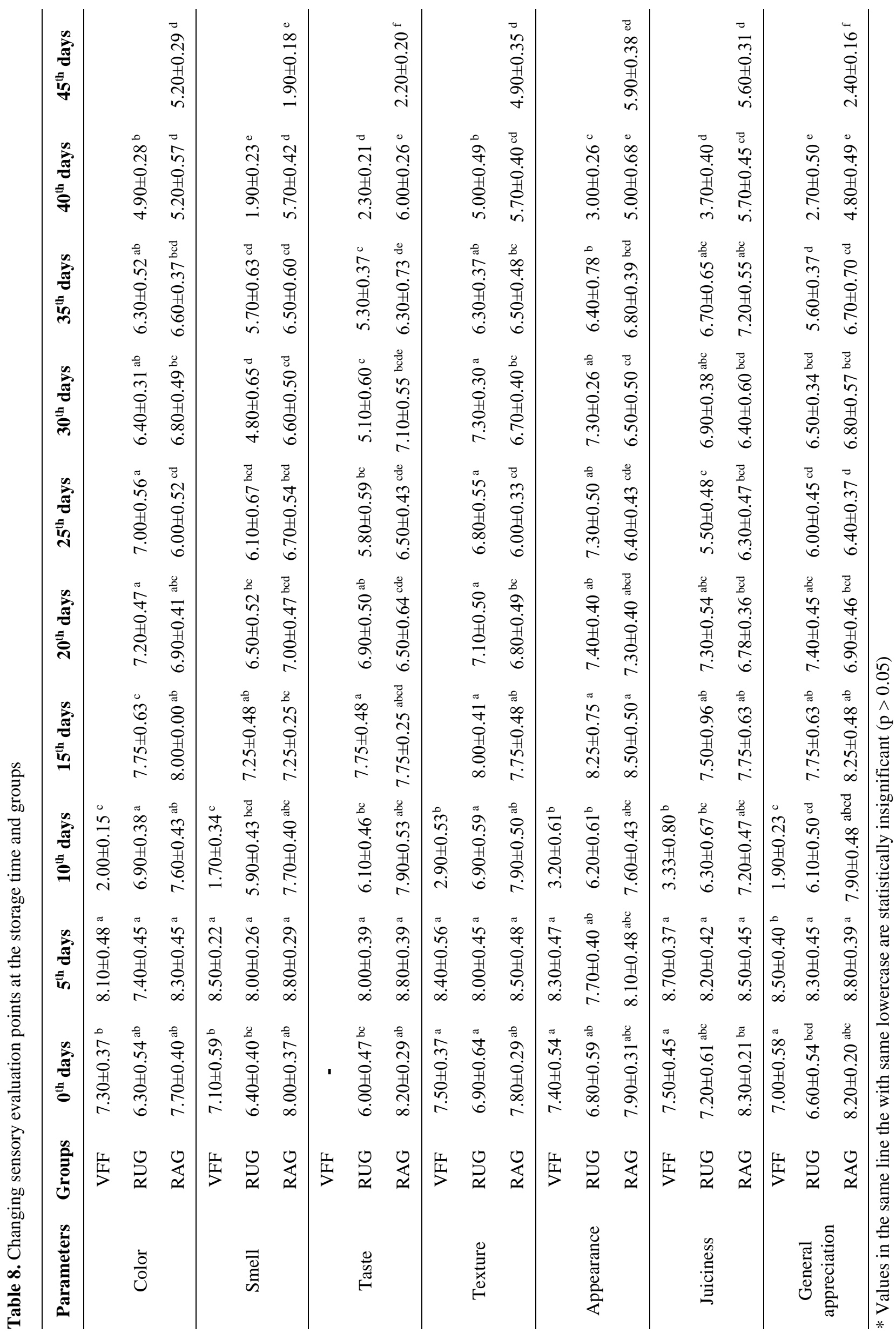




\section{References}

Abramovic H, Terpininc P, Generalic I, Skroza D, Klancnik A, Katalinic V, Mozina SS. 2012. Antioxidant and antimicrobial of extracts obtained from rosemary (Rosmarinus officinalis) and vine (Vitis vinifera) leaves. Croat J Food Sci. Technol 4(1):1-8

Alasalvar C, Shahidi, F, Miyashita K, Wanasundara U. 2011. Seafood quality, safety and health aplication. In Alasalvar C, Shahidi F, Miyashita K, Wanasundara U. (Ed.), Handbook of Seafood Quality, Safety and Health Application, (1-10). UK: Blackwell Publishing. 542 p.

Altınelataman C, Kışla D, Kılınç B, Yılmaz EBŞ, Yünlü AC, Dinçer T, Çelik U. 2015. Antioxidant, antimicrobial and sensorial effects of rosemary (Rosmarinus officinalis L.) and sage (Salvia officinalis L.) on sea bass (Dicentrarchus labrax L.) fillets. Ege J Fish Aqua Sci 32(3):121-126. doi: 10.12714/egejfas.2015.32.3.01

Altuğ T, Elmacı Y. 2005. Gidalarda duyusal değerlendirme. İzmir: Meta Basım Matbacılık Hizmetleri. 130p. [in Turkish]

AOAC 2000. AOAC Official Method 940.25 Nitrogen (total) in seafood. First Action 1940, Official Methods of Analysis of AOAC International $17^{\text {th }} \mathrm{Ed}$.

Azizkhani M, Tooryan F. 2015. Antioxidant and antimicrobial activities of rosemary extract, mint extract and a mixture of tocopherols in beef sausage during storage At 4c. J Food Safety 35(1):128-136. doi: $10.1111 /$ jfs. 12166

Bilen G. 2009. The effects of natural antioxidants on the quality of frozen fish. [Master's Thesis] İstanbul University. 98 p. [in Turkish]

Bolton DJ. 1998. The microbiological safety and quality of foods processed by the sous vide system as a method of commercial catering. The National Food Centre, Dunsinea, Castleknock, 14 P, Dublin. Project armis No. 4031

Cadun A, Caklı S, Kisla D. 2005. A study of marination of deep water pink shrimp (Parapenaeus longirostris, Lucas, 1846) and its shelf life. Food Chem. 90(2005):53-59.

doi: 0.1016/j.foodchem.2004.03.024

Cobos A, Diaz O. 2007. Sous-vide cooking of traditional meat products: effect on the microbiology of dry-cured pork foreleg. Communicating Current Research and Educational Topics and Trends in Applied Microbiology A. Méndez-Vilas (Ed.). 511-517. [cited: 04.04.2017] Available from http://www.formatex.org/microbio/pdf/Pages511-517.pdf

Cosansu S, Mol S, Alakavuk DU, Özturan S. 2011a. The effect of lemon juice on shelf life of sous vide packaged whiting (Merlangius merlangus euxinus, Nordmann, 1840). Food Bioprocess Tech. 6(1):283-289

doi: 10.1007/s11947-011-0572-0

Cosansu S, Mol S, Alakavuk DU, Özturan S. 2011b. The effect of lemon juice on bonito (Sarda sarda, Bloch, 1793) preserved by sous vide packaging. Int J Food Science and Technol. 46(29):395-401. doi: $10.1111 / \mathrm{j} .1365-2621.2010 .02507 . x$
Çaklı S, Kılınç B. 2003. A study on marination of sardine (Sardina pilchardus, W.1792) fillets. Izmir:TÜBİTAK. Proje No: VHAG-1839 (101V130). $77 \mathrm{p}$ [in Turkish]

Çaklı Ş. 2007. Su ürünleri işleme teknolojisi 1. İzmir: Ege Üniversitesi Basımevi, 696p. [in Turkish]

Dapkevicius A, Venskutonis R, van Beek TA, Linssen JPH. 1998. Antioxidant activity of extracts obtained by different 1solation procedures from some aromatic herbs grown in lithuania. J Sci Food Agric. 77(1):140-146. doi:10.1002/(SICI)1097-0010(199805)77:1<140:: AID-JSFA18>3.0.CO;2-K

Diaz P, Nieto G, Garrido MD, Banon S. 2008. Microbial, physical-chemical and sensory spoilage during the refrigerated storage of cooked pork loin processed by the sous vide method. Meat Sci. 80(2): 287-292. doi:10.1016/j.meatsci.2007.12.002

Diaz P, Nieto G, Banon S, Garido MD. 2009. Determination of shelf life of sous vide salmon (Salmo salard) based on sensory attributes. J Food Sci. 74(8):371-376. doi: 10.1111/j.1750-3841.2009.01317.x

Diaz P, Garrido MD, Banon S. 2010. The effects of packaging method (vacuum pouch vs. plastic tray) on spoilage in a cook-chill pork-based dish kept under refrigeration. Meat Sci. 84(3):538-544. doi: 10.1016/j.meatsci.2009.10.009

Diaz P, Garrido MD, Banon S. 2011. Spoilage of sous vide cooked salmon (Salmo salar) stored under refrigeration. Food Sci Technol Int. 17(1):31-37. doi: 10.1177/1082013210368744

Diri M. 2006a. Analysis of essential oil of Coridothymus capitatus (L.) Reichb. and determination of antioxıdant activity of its water and ethanol extracts. [Master's Thesis]. Muğla Üniversitesi $101 \mathrm{~s}$. [in Turkish].

Diri HA. 2006b. Characterization of essential compositions and determination of antioxidant activity of Salvia candidissima vahl. [Master's Thesis]. Muğla Üniversitesi. 119 s. [in Turkish].

Dokuzlu C. 1997. Marinat hamsi üretimi sırasında kullanılan asit - tuz oranlarının ürünün mikrobiyolojik ve organoleptik kalitesi üzerine etkileri ve raf ömrünün belirlenmesi. Pendik Veteriner ve Mikrobiyoloji Dergisi. 28(1):81-90. [in Turkish]

Erdem ME, Bilgin S, Çağlak E. 2005. tuzlanmış ve marinasyon yöntemleri ile işlenmiş istavrit balığı'nın (Trachurus mediterraneus, Steindachner, 1868) muhafazası sırasında kalite değişimleri. J of Fac of Agric. OMU. 20(3):1-6. [in Turkish]

Erkan N, Özden Ö. 2008. Quality assessment of whole and gutted sardines (Sardina pilchardus) stored in ice. Int J Food Sci Tech. 43(9)1507-1727. doi:10.1111/j.1365-2621.2007.01579.x

Eseceli H, Değirmencioğlu A, Kahraman R. 2006. Omega yağ asitlerinin insan sağlığı yönünden önemi. Paper presented at: Türkiye 9. Gıda Kongresi. Bolu, Türkiye. [in Turkish]

Fagan JD, Gormley TR. 2005. Effect of sous vide cooking, with freezing, on selected quality parameters of seven 
fish species in a range of sauces. Eur Food Res Technol. 220(3):299-304. doi: 10.1007/s00217-004-1028-9

Fallah AF, Saei-Dehkordi SS, Nematollahi A. 2011. Comparative assessment of proximate composition, physicochemical parameters, fatty acid profile and mineral content in farmed and wild rainbow trout (Oncorhynchus mykiss). Int J Food Sci Tech. 46 (4):767-773. doi: 10.1111/j.1365-2621.2011.02554.x

Fernandez J, Perez-Alvarez AJ, Fernandez-Lopez JA. 1997. Thiobarbituric acid test for monitoring lipid oxidation in meat. Food Chem. 59(3):345-353. doi:10.1016/S0308-8146(96)00114-8

Garcia-Linares MC, Gonzales-Fandos E, GarciaFernandez MC, Garcia-Arias MT. 2004. Microbiological and nutritional quality of sous vide or traditionally processed: influence of fat content. J Food Quality. 27(5):371-387. doi: 10.1111/j.1745-4557.2004.00676.x

Genena AK, Hense H, Junıor AS, de Souza SM. 2008. Rosemary (Rosmarinus officinalis) a study of the composition, antioxidant and antimicrobial activities of extracts obtained with supercritical carbon dioxide. Ciênc Tecnol Aliment. 28(2):463-469 doi: 10.1590/S0101-20612008000200030

Gonzales-Fandos E, Garcia-Linares MC, VillarinoRodriguez A, Garcia-Arias MT, Garcia-Fernandez MC. 2004. Evaluation of the microbiological safety and sensory quality of rainbow trout (Oncorhynchus mykiss) processed by the sous vide method. Food Microbiol. 21(2):193-201. doi: 10.1016/S0740-0020(03)00053-4

Gonzales-Fandos E, Villarino-Rodriguez A, GarciaLinares MC, Garcia-Arias MT, Garcia-Fernandez MC, 2005. Microbiological safety and sensory characteristics of salmon slices processed by the sous vide method. Food Control. 16(1):77-85. doi: 10.1016/j.foodcont.2003.11.011

Gülyavuz H, Ünlüsayın M. 1999. Su ürünleri isleme teknolojisi. Ankara: Şahin Matbaası. 366p. [in Turkish]

Huss HH. 1995. Quality and quality changes in fresh fish. Rome. Fao Fisheries Technical Paper-348. 172p.

Kenar M, Özoğul F, Kuley E. 2010. Effects of rosemary and sage tea extracts on the sensory, chemical and microbiological changes of vacuum-packed and refrigerated sardine (Sardina pilchardus) fillets. Int J Food Sci Tech. 45(11):2366-2372. doi: 10.1111/j.1365-2621.2010.02414.x

Kılınç B, Çaklı Ş. 2001. Packaging technics, the effects on microbial flora of fish and shellfish. Ege J Fish Aqua Sci. 18(1-2):279-291. [in Turkish].

Klancnık A, Guzej B, Kolar MH, Abramovic H, Mozına SS. 2009. In vitro antimicrobial and antioxidant activity of commercial rosemary extract formulations. J Food Protection. 72(8):1744- 1752. doi: 10.4315/0362-028X-72.8.1744

Lindström M, Nevas M, Hielm S, Lähteenmäki L, Peck MW, Korkeala, H. 2003. Thermal inactivation of nonproteolytic Clostridium botulinum type e spores in model fish media and in vacuum-packaged hot- smoked fish products. Appl Environ Microbiol. 69(7):4029-4036.

doi: 10.1128/AEM.69.7.4029-4036.2003

Lovell RT. 1981. Laboratory manuel for fish feed analysis and fish nutrition studies. Alabama. Department of Fisheries and Allied Aquacultures International Center for Aquaculture. Auburn University. 65p.

Meskin SM, Bidlack RW, Randolph RK. 2008. Phytochemicals aging and health. Boca Raton:CRC Press. 205 p.

Mol S, Özturan S. 2009. Sous-vide teknolojisi ve su ürünlerindeki uygulamalar. Journal of Fisheriessciences.com. 3(1):68-75. [in Turkish] doi: 10.3153/jfscom.2009010

Mol S, Ozturan S, Cosansu S. 2012a. Determination of the quality and shelf life of sous vide packaged bonito (Sarda sarda, Bloch, 1793) stored at 4 and $12{ }^{\circ} \mathrm{C}$. J Food Quality. 35(2):137-143. doi: 10.1111/j.1745-4557.2011.00430.x

Mol S, Ozturan S, Cosansu S. 2012b. Determination of the quality and shelf life of sous vide packaged whiting (Merlangius merlangus euxinus, Nordman, 1840) stored at cold $(4 \mathrm{c})$ and temperature abuse $\left(12^{\circ} \mathrm{C}\right)$. J Food Process Pres. 36(6): 497-503. doi: 10.1111/j.1745-4549.2011.00616.x

Nicholas TA. 2003. Antimicrobial use of native and enzymatically degraded chitosans for seafood aplications. [Master Thesis]. The University of Maine. $130 \mathrm{p}$.

Nollet LML, Toldrá F. 2010. Seafood and seafood products analysis. Boca Raton: CRC Press. 910p.

Novak JS, Sapers GM, Juneja VK. 2003. Microbial safety of minimally processed foods. Boca Raton: CRC Press LLC. 343p.

Oktay M, Gülçin İ, Küfrevioğlu Öİ. 2003. Determination of in vitro antioksidant activity of fennel (Foeniculum vulgare) seed extracts. LWT - Food Sci Tech. 36(2):263-271. doi: 10.1016/S0023-6438(02)00226-8

Özdamar K. 2001. SPSS ile biyoistatistik. Eskişehir: Kaan Kitabevi. 452p. [in Turkish]

Özden Ö, Metin S, Baygar T, Erkan N. 2001. Vakum paketlenmiş marine balıkların kalitesinin belirlenmesinde yağ asitleri ve aminoasit bileşimindeki değişimlerin incelenmesi. İstanbul: TÜBİTAK, Proje No: VHAG-1713/ADP, 29s. [in Turkish]

Özturan S. 2009. Determination of the quality and shelf life of cooked fish in vacuum package (sous vide) [Master Thesis]. Istanbul University. 94p. [in Turkish]

Peck MW. 1997. Clostridium botulinum and the safety of refrigerated foods of extended durability. Trends Food Sci Tech. 8(6):186-192. doi: 10.1016/S0924-2244(97)01027

Poyrazoğlu ES, Velioğlu S. 2005. Beta karotenin oksidasyonuna sıcaklık, 1şık, süre ve gallik asitin etkisi. Gıda Müh Der. 20: 50-54.

Ruiz-Capillas C, Gillyon CM, Horner WFA. 2001. Determination of different volatile base components as quality control indices in fish by official methods 
and flow injection analysis. $\mathrm{J}$ Food Biochem. 25(6):541-553.

doi: 10.1111/j.1745-4514.2001.tb00813.x

Selmi S, Sadok S. 2008. The effect of natural antioksidant (Thymus vulgaris (Linnaeus)) on flesh quality of tuna (Thunnus thynnus (Linnaeus)) during chilled storage. Pan-Am J Aqua Sci. 3(1):36-45.

Shakila JR, Jeyasekaran G, Vijyakumar A, Sukumar D. 2009. Microbiological quality of sous-vide cook chill fish cakes during chilled storage $\left(3^{\circ} \mathrm{C}\right)$. Int J Food Sci Tech. 44(11):2120-2126. doi: 10.1111/j.1365-2621.2009.02047.x

Shakila RJ, Raj BE, Felix N. 2012. Quality and safety of fish curry processed by sous vide cook chilled and hot filled technology process during refrigerated storage. Food Sci Technol Int. 18(3):261-269. doi: $10.1177 / 1082013211415177$

Soyer A. 1995. Effect of some antioxidants and vacuum packaging on lipid oxidation of frozen chub mackerel (Scomber japonicus). [Doctorate Thesis]. Ankara University. 91 p. [in Turkish]
SVAC. 1991. Code of practice for sous vide catering system. Tetbury, Gloucestershire, UK.

Tepe B, Daferera D, Sokmen A, Sokmen M, Polissiou M. 2005. Antimicrobial and antioxidant activities of the essential oil and various extracts of Salvia tomentosa Miller (Lamiaceae). Food Chem. 90(3):333-340. doi: 10.1016/j.foodchem.2003.09.013

Uçak İ, Özogul Y, Durmuş, M. 2011. The effects of rosemary extract combination with vacuum packing on the quality changes of atlantic mackerel fish burgers. Int J Food Sci Tech. 46(6):1157-1163 doi: 10.1111/j.1365-2621.2011.02610.x

Vareltzis K, Koufidis D, Gavriilidou E, Papavergou E, Vasiliadou S. 1997. Effectiveness of a natural rosemary (Rosmarinus officinalis) extract on the stability of filleted and minced fish during frozen storage. Z Lebensm Unters Forscf A. 205(2):93-96. doi: 10.1007/s002170050131

Varlık C, Özden Ö, Erkan N, Alakavuk DÜ. 2007. Su ürünlerinde temel kalite kontrol. İstanbul: İstanbul Üniversitesi Basım ve Yayınevi Müdürlüğü 202 p. [in Turkish] 